\title{
Towards Expanding the Frontiers of Accounting Knowledge: Imperative for Practitioners Accommodation
}

\author{
Stanley Ogoun \\ Department of Accountancy, Faculty of Management Sciences, Niger Delta University, Wilberforce Island, Bayelsa State, Nigeria \\ Email address: \\ stanleyogoun@ndu.edu.ng, stanleyogoun@gmail.com \\ To cite this article: \\ Stanley Ogoun. Towards Expanding the Frontiers of Accounting Knowledge: Imperative for Practitioners Accommodation. Journal of \\ Finance and Accounting. Vol. 8, No. 2, 2020, pp. 73-82. doi: 10.11648/j.jfa.20200802.13
}

Received: March 9, 2020; Accepted: March 25, 2020; Published: April 17, 2020

\begin{abstract}
This study explored the role of accounting professional practice in shaping the expansion of the frontiers of accounting knowledge. This was based on the reality and imminence of the threat posed by developments in artificial intelligence, premised on tech-developmental disruptions, the gap between accounting theoreticians and practitioners, and accounting's back-lead in new knowledge development and application. As gleaned from the preponderance of theoretical evidence, which underscores practitioners' continuing preference for normative, descriptive, and immediate problemresolution research, the study concludes that expanding the frontiers of accounting knowledge has been budged down, by the limited scope of practice accommodation given to new knowledge deployment. Thus, for as long as practitioners foreclose new knowledge deployment, a consummate expansion of the accounting knowledge base cannot be actualised. Accounting would continue to blaze the backward-trail in new knowledge development, relative to other academic disciplines and professional practice. Therefore, accounting practitioners must be willing to accommodate knowledge expansion in light of society's continued advancement. While, at the same time, researchers must indulge practitioners in a gradual shift to new research output indulgence, so as not to cause too much dislocation. Again, practitioners, for the sake of saving the accounting field, should be willing to fund futuristic research. Finally, accounting practitioners should be prepared to accommodate some degree of risk arising from new knowledge deployment.
\end{abstract}

Keywords: Frontiers, Accounting Knowledge, Practitioners, Tech-disruptions, Career Path, Development

\section{Introduction}

Technological innovations and nuances have caused and will continue to drive a great deal of change around the globe Stellar and complex creative innovations have shaped our contemporary world and caused significant disruptions. These astronomical advances in technology and, in particular, artificial intelligence (AI) are curiously shaping what is now designated as the 'fourth industrial revolution.' Technological advances in AI in real terms, have come at such unimagined magnitude and disruptions to so many aspects of traditional socio-economic interactions, while at the same time, progressively benefiting several other domains of social interfaces. The negatives are borne severely by aspects of societal dealings, that were once thought of as sacrosanct and sacred. The aspects of societal life, where the negatives weigh heavily, fall within those traditional areas of life that hindsight of the impacts of future human developmental aspirations were never projected and hedging provided for. The apparent reality is that these aspects of society were overtaken by the overwhelming force of these stellar developments. Today, and undoubtedly, several routine jobs and careers have become extinct and more are likely to go down the same path. The result is, warning by some pundits and skeptics of the dark sides of technology, with its potentials for obliterating the human race. As can be seen in most advanced technology-driven industries, the massive role of robotics is mind-boggling. Traditional careers and jobs are fast becoming extinct. Formal work structures are being altered into informal streams of lean, sophisticated and yet cost-effective operational typologies.

A further fallout of these massive human advancements, is the near-complete obliteration of the formal business environment, that was once differentiated by big and large physical assets holding firms, with massive structures. As can 
be seen today, the leading firms with sterling market value are apps-based and driven, but lacking any of the traditional forms of major physical assets holding. Thus, invariably altering the organizational structure landscape. Following this, is the massive cost management efficiency of the techdriven business operational models, which has enabled them to gain massive competitive advantage over their traditional counterparts. The reality to any keen observer is that, the entire conventional business operation landscape, is being altered for a tech-driven one, devoid of the structural oligarchies of the oligopolists of the past.

The foregoing contemporary attributes designation of our business world, denotes that the flow of financial information has also been altered from its traditional tenure. These breakthroughs have economically amalgamated and compressed the four corners of the world into a global village. Business transactions are now easily made electronically within seconds and minutes; with little or no physical cash, via the net, and this has also increased the volume of transactions. Going forward, financial transactions are daily becoming complex, due to the sophisticated means of operations carried out by individuals, whose identities are not physically verified. Part of the implications of this attribute designation of the inform-tech and the emerging AI revolution, is the shifting of the traditional forms of physically situated market-based operations to online and real-time models, characterized by speed, comfort, and convenience. The volume of online market activities is out of space and never anticipated a few decades ago.

To be relevant in the contemporary scene, financial information must of necessity be tracked and trapped, along the nerves of the ongoing novel business template for meaningful decision making. Doesn't this presuppose the urgent need for the espousal of new accounting methodologies and expanding the frontiers of the epistemology of accounting science and practice? If this is not contemplated and acted upon, would accounting not loose its relevance as an information science? Also, concerns should be raised as to what is the likelihood that developments in AI will not eliminate the traditional human accounting career path, if accounting does not assume a techdriven and AI compliant paradigm?

The foregoing reality template, juxtaposed against the conservative nature of traditional accounting practice and philosophy, portends great danger for accounting's future relevance. From a comparative milieu, amongst disciplines and epistemological domains in the field of management sciences, there is a clear indication of accounting knowledge growth's trailing heavily behind its contemporaries in management, finance, and marketing. Various new theoretical and epistemological grounds have been covered and are being covered in these other allied disciplines. Comparatively, accounting has blazed the backward trail in new knowledge development spheres. Traditional grounds for theoretical espousals that govern accounting practice, (primarily the domain of financial accounting) has come under severe criticisms. Applications of new developments like Current Cost
Accounting (CCA) or Inflationary or Real Price Accounting, Human Resource Accounting (HRA), Environmental Accounting (EA) amongst others, are hardly implemented in the returned annual financial reports. Traditional practice procedures, enshrined in the conservative philosophical mainframe of accounting practice, has foreclosed the implementation of new accounting methodologies. Furthermore, besides the growth in ICT and its attendant challenges, is the infiltration of new knowledge from allied disciplines; like economics, management, sociology, etc., which has given practitioners in the accounting profession great concern in meeting the expectations of the business community. Thus, practitioners are bedeviled with new concepts, techniques and knowledge such as Social and Environmental Reporting, Employee Accounting, Oil and Gas Accounting, Forensic Accounting, Medium Term Expenditure Framework (MTEF), alternative approaches to budgeting such as Zero-Based Budgeting (ZBB), Programme Performance Budgeting System (PPBS), Activity Based Budgeting (ABB), Target Costing, etc.

The pragmatic and increasingly complex current and future business operational template, implies that the relevance of the traditional accounting milieu is highly questionable in the next century. This is because techadvances and breakthroughs, are altering the conventional accounting information-chain. For the accountancy profession to retain the credibility and trust it has cultivated and enjoyed in the past, shouldn't it follow the trend in advancements? Doesn't this invariably call for accounting practitioners to be forward-looking? However, the reality is that expanding the frontiers of knowledge is not a tea party. Knowledge expansion is a rigorous and time-consuming art, which is indicative of the truth that routine accounting operational platforms do not provide the enabling environment to nurture and prop-up far-reaching ideas, even when such platforms can ignite the need for new knowledge. Structural rigidities foreclose such innovations, necessitating a theory-practice convergence model. The fact however, is the existence and continuously widening gap. This gap is well accentuated in the scholarly works of ([10, 16, 23, 35-37, $39,40,42,46,60])$ amongst several others. Also, at various fora, practitioners and academics have complained of this gap, and extended the debate to providing solutions.

The natural corollary from this gap, juxtaposed against the looming reality of inform-tech alteration of the traditional accounting playing field, is that in no time, wouldn't traditional accounting practice become extinct? Would it not be purely AI-driven on application platforms? It is this motivation that informed the need to incur into the dilemma of constraints of expanding the frontiers of accounting knowledge, the practitioners' accommodation paradigm?

\section{The Literature Basis}

\subsection{The Theory-Practice Gap in Accounting Domain}

It is sacrosanct to note from the onset that the theorypractice or research-practice gap debacle, is not confined to 
the accounting domain. Evidence from various fields of study and social practices have documentations of the existence of such gaps, with efforts at bridging them. However, in most other areas, the gap has become very narrow, if not almost none-existent. The narrowed or almost non-existence gap, is more pronounced in domains where theory building, is at the frontiers of knowledge growth and where theory leads to practice. In some other areas, both theory and practice are intertwined in an inseparable tie, that sometimes practice related dilemmas, ignite search for new theories. These fields have made significant progress as evidenced in the technology-driven domains. However, in accounting, the structure of practice is more regimented and does not allow for individual innovation and imagination. The rules must be followed, which must have been generally accepted by all. Notably, the template for financial accounting engagement does not leave room for any form of imaginative ideation. Thus, before the adoption of the International Financial Reporting Standards (IFRS), various accounting jurisdictions existed, requiring absolute compliance with their predetermined financial reporting dogma. As currently, the US still holds on to its GAAP for financial reporting. Thus, a close diagnosis of this practice form, signposts new theory application foreclosure.

In a scholarly effort to identify the gap causative gen, [6], traced the evolutionary path of modern accounting education and deposed that at the heart of the problem, lies the very nature of contemporary accounting development itself. From his trace analysis, he observed that accounting came to being and existed as a practice or doing act. He deposed the reality that, while the Humanities (i.e., philosophy, psychology, etc.), Social Sciences (i.e., economics) and Physical Sciences had long been established and recognized as distinct fields of human knowledge in the early $19^{\text {th }}$ century in the US, the business discipline evolved later on, with accounting coming much later. In this context, early accounting research [6] was "both descriptive and normative, involving prescriptions concerning the correct way to account for economic transactions." In appraising this expose' [6] "reported that before the 1960s, accounting academia was oriented towards practice: education was focused on solving practical problems, faculty members had only professional certifications and significant practical experience, and research was mostly practice-oriented." No wonder, there were hardly doctoral degree holders in accounting before the 1960s.

From the work of [6], the gap began with the introduction of the philosophical (doctoral) degree level in the accounting discipline. He traced the history to when in 1959, the call was made to deploy scientific methodologies to business, away from the earlier practical approach, by the duo of Deans of business schools in the US, which attracted funding from the Ford Foundation. This began the era of philosophizing and the deployment of scientific methodologies. The rule-based practice model was bound to create conflict with the scientific template. "This was the start of evolution towards the use of complex research methodologies, and theories as to the foundation of accounting research, and generally towards sophistication [6]." In essence, the rule-based practice paradigm was bound to be a mismatch with the scientific typology, that accommodates individual creativity and extemporaneousness. The hallmark of science is an indepth imaginative thought process, via a systematic methodology towards excavating the truth (pure research) or solving human problems (applied). The rigid framework of traditional accounting practice, leaves no leverage for such thoughtful individual or group creative enactments. Conventional accounting practice thrives on the wheels of conservatism and rule compliance, and anything outside this is considered a procedural breach.

From the works of $([7,15,20,22,27,35,40,43-46,51,58$, $59,60]$ ) amongst others, the basis for the gap beyond the excellent historical pedigree of accounting evolution, were designated. The sophistication in research methodologies, via the deployment of exotic theories and mathematical rigours, the quantum and dispersion of research, timing, language, unwillingness of practitioners to engage and lack of interest in research, lack of motivation on the part of practitioners to read, reluctance to disclose data, self-interest and inherent differences in focus, etc were mulled as the key drivers of the gap. [60] deposed further that, differences in language, time essence, motives, ideologies, knowledge and expertise, incentives, values, agenda, and perceived roles, also accounts for the continued existence of the gap. Furthermore, I supposed that routine practice allows for comfort. Thus, the fear of moving out of the routine and rule-based practice domain, also accounts for the gap. The willingness to try out new methodologies negates the very essence of the current FA accounting template, which does not accommodate new knowledge engagement.

My deposition is that, given the current efforts at scientific tooling of the accounting discipline, towards a truly theorydriven domain, and the accentuated efforts to align accounting knowledge growth with a strong scientific foundation, implies that the scale for alignment requirement begs for more attention from practitioners. Accounting is a service function. It is a means to an end and not an end in itself. Accounting is simply a financial information science, geared towards providing decision-useful information. It's inform-support function, denotes its primary relevance and purpose of being. Meanwhile, the field where the informgathering occurs, is changing in leaps and bounds. Transactions have become more complex, the traditional nature of firms is increasingly becoming obsolete. Nonformal partnership business models are being espoused through alliances and integrated networks. The reality is that the operational practice template is changing, such that holding on to traditional forms may be disastrous.

Also, various academic disciplines are aligning with integrated research. Academic discipline silos are disappearing fast, with research funds being directed to multi-disciplinary research teams. Academic research alliances that were once thought of as forbidden and impossible, are a reality today. Research integration via 
alignment and synergy is now the model for obtaining research grants. The fact is that accounting practitioners never got out of the practice and rule-based dogma, that characterised early accounting development, such that at the point where philosophizing via the scientific template was evoked, practitioners remained glued to their old form. Their unwillingness to try out new knowledge accounts for the slow pace of accounting knowledge expansion. Proper scrutiny of even the IFRS framework, throws up the reality, that, it is still a re-enactment of rules. For instance, it has been widely accepted that the human asset is the greatest asset of a business. However several years down the line, the existing financial accounting rule-based reporting template is yet to make provision for its valuation in financial reports, despite the emergence of human resource accounting, talkless of CCA, ECA, etc. Also, the continuous assessment of the land asset at historical cost, until revaluation and or sale negates reality reporting. The non-inclusion of these new developments, is a reflection of the scope of leverage practitioners are willing to give to accounting knowledge frontier expansion, serious implications for complete of reported earnings.. How does the exclusion of material information of the most important asset of an entity, not negate the principle of complete reporting? Shouldn't there be a search for ways and means of overcoming the challenges with such data set generation for financial reporting inclusion? Furthermore, the old critique of the unrealistic nature of accounting reported profits still begs for attention, several years down the line.

\subsection{Bridging the Gap from the Existing Literature Template}

The stack realisation of the existence of the researchpractice gap by both sides of the divide did ignite some suggestions on how to bridge the gap. From the body of extant literature, gleaned from the works of ([13, 19, 28, 31, $33,38,41,49,51,52,54-56,58,60])$, amongst several others, the following: research collaborations between both parties, attendance of mixed grill conferences and symposia (researchers and practitioners together), forming both sides facilitated dialogues, proper research output dissemination, real and significant data sharing, conducting specific practice-based problem research, develop research questions based on practitioners' needs, sharing of research agenda, agenda integration, adopting interdisciplinary approach to accounting research, educating practitioners on how to read, interpret and utilize research outcomes, better communication between both parties, developing consulting relationships, practitioners reviewing academic journals, reliance of consultants to bridge the gap, altering academic career growth model to attract practice-based research, instituting awards and recognition for undertaking problembased research amongst faculty staff were proferred. Also, the deployment of diffusion theory $([17,30])$, which entails navigating the discovery-translation-dissemination-change chain, have been canvassed by [59].

The foregoing numerous propositions are indicative of how nagging the problem is. However, the focus of this study is not to add to the already choked milieu of remedies, but tailored towards instigating self-realisation and awakening of the consciousness of practitioners to the reality that the future does not hold sustenance for the current human practice dominated accounting model. Contrarily, academics can continue to theorize, by integrating and synergizing accounting research within the current model of multidisciplinary research engagement and subsequent knowledge expansion.

\subsection{The Imperative of a Theoretical Base for Accounting Knowledge Growth}

The current reality of an increase in knowledge is that theory is central. For instance, [46] deposed that discovery is "the means by which knowledge grows and therefore that discovery is the creation of knowledge through rigorous research, that provides the scientific foundation of a discipline." Hence, the observation by [11] that accounting is a middle science needs accentuating. This deposition is borne out of the absence of a truly accounting theory, which gives impetus to the questioning of some of the outputs of existing accounting methodologies. Accounting must pull itself together and out of the borrowed theory jungle, towards evolving a truly accounting theory, even if it involves exploiting the 'corridor principle' or real adaptation of related approaches. For instance, in highlighting the place of philosophy, [48] opined that "research data can, should, does, and will continue to affect the effectiveness and efficiency of individual firms, not-for-profit oriented organizations, governments, and capital markets, as well as the governance of these entities and markets." This deposition anchors the mundane status of the rule of the thumb approach in new knowledge building sites. Thus, [26] argued that academics must undertake the challenge of building a genuinely academic discipline. In support of this deposition, [35] had earlier described accounting research as not only relevant, but as a theory-driven process, that systematically inquires into a particular matter, with the purpose of uncovering novel ideas and critical diagnosis of current knowledge. It is expected that the output would not only contribute to knowledge, but engender a change. This position aligns with the diffusion theory template.

Drawing from the foregoing, a definitional deposition of the Knowledge construct is inevitable as the basis for anchoring the import of theory escalation in the accounting gap discourse. Hence, to [59], knowledge is "a fluid mix of framed experiences, values, contextual information, and expert insight, that offers a framework for evaluating and incorporating new experiences and information." In another definition by [60], knowledge is seen as an intangible asset acquired by a composite and rigorous process, involving perception, learning, communication, association, and reasoning. These depositions underscore the reality that scientific knowledge acquisition is a painstaking process, demanding conscious effort. Meanwhile, to [20], it is primarily an embodiment of information. Information 
processed by individuals, including ideas, facts, expertise, and verdict relevant to individuals, team, and organizational performance denotes knowledge [59], and it is information combined with experience, context, interpretation, reflection, and perspective, which adds a new level of insight. Knowledge, therefore, is an embodiment of truth about a phenomenon that shapes our understanding of the world around us and how we live.

From the foregoing review, knowledge can be acquired in different ways. The literature has various documented routes for acquiring knowledge. The basic one, is the informal, or traditional home-grown narrative paradigm, followed closely by the experiential model. It is a truism that experience is not taught as a course in the classroom, but it is a hands-on process. Not withstanding, circumstantial variations alter the expected outcome of each of these first-type knowledge acquisition methodologies. These two typologies do not fall into a formal and structured model, and do not align the scientific frame of knowledge construct. Scientific knowledge denotes that which is acquired via a systematic and rigurous process, bounded within the tenets of a repeated verifiable template. The output of the experimental knowledge basket is what shapes our current world, and this accounts for the current scientific teleological push of all mainframe fields of knowledge. By implication, the continuous relevance of future accounting knowledge must be birthed on the bowels of scientific methodologies. Accounting science must evolve through scientific theoretical espousals, characterized by verifiability.

The stack reality is that accounting knowledge expansion must be scientific-driven via theoretical collocation, if it must maintain its relevance in the coming industrial revolution. Anything short of this, is a recipe for extinction, in a fast scientific-driven world. The current subjectivism profile of accounting practice would give way to empiricism, once theoretical espousals take the lead. Although, [7] have cautioned that the goal of accounting research, as a social science domain construct, is not behaviour modification for the practicing accountant, but rather to apprehend and give a narrative of the behaviour of the accountant. Be that as it may, accounting can no longer operate in a silo, it must re-invent itself via scientific adaption to hedge relevance lost.

\subsection{Some Empirical Instances of New Knowledge Discovery, but Jettisoned in Practice}

The accounting profession has recorded a lot of new knowledge in the 21 st century. Almost all the branches of accounting have advanced philosophies in one form or the other. This has also increased the number of courses taught in the discipline in the academic setting. Thus, the expansion of knowledge in the discipline has given birth to new topics and courses like forensic accounting, oil and gas accounting, social and environmental accounting, employee accounting, etc. The question, however, is, how are practitioners in the accountancy profession engaging these innovations in daily accounting practice?

\subsubsection{The Financial Accounting and Reporting Domain}

One major area where accounting knowledge has dynamically increased is in financial accounting and reporting. Research findings of [1] states that economic efficiency, though necessary, is now not the ultimate factor in business sustainability in the 21 st century. They argued that organisations are now expected to be socially and environmentally responsible. Thus, a trending concept in the field of financial accounting and reporting is corporate social responsibility, which necessitates social and environmental reporting or accounting. According to [29], environmental and social accounting and reporting are growing and increasingly becoming essential activities. They argued that the increasing importance of environmental issues and the reemerging awareness of the social dimensions of organizations, now constitute a vital factor for organisational sustainability. Hence, the business society has come to a point where environmental and social accounting and reporting are not only crucial, but a must. In line with the above assertion, prior research revealed that social and environmental accounting is well-practiced in developed countries and economies, but [1] observed that accounting practitioners and corporate organisations are yet to embrace it in developing countries like Nigeria fully.

Another challenge in financial reporting in the information age is "transparency and objective financial disclosure." Transparency is the principle of creating an atmosphere where information on existing conditions, decisions, and actions are made accessible, visible and comprehensible to all interested users. A breakthrough however in this area is the reconciliation or harmonization of the US GAAPs and the European IAS which led to the emergence of IFRSs in 2005. One of the cardinal objectives of IFRSs is transparency and objective disclosure, but the question is, to what extent do vital players (i.e. Board members) in contemporary complex and resilient financial systems, permiting practicing accountants and auditors to prepare and report financial activities according to the dictates of IFRSs? It is worrisome to observe that IFRSs is yet to record the international cogency, as the US and some developing countries are, however, yet to embrace IFRSs as their basis of financial reporting fully. There is, therefore, a gap in the financial reporting pattern in the world of business.

Closely related to the above challenge is financial reporting in a chronologically inflationary environment. During inflation, the monetary measurements of economic activities or transactions evokes doubt and are highly questionable. This is because inflation can lead to unrecognized gains, which are capable of distorting the actual figures of future cash flows. Above all, inflationadjusted data is inconsequential for decision making. Despite the two basic methods of accounting for inflation (Current Purchasing Power and Current Cost Accounting), practitioners are yet to fully integrate this into the regular reporting template. More so, the accounting profession is, however, yet to come up with a unified method to handle this menace, thereby leaving it to the discretion of directors and 
management of firms.

Furthermore, the increasing use of novel and often complex financing arrangements of off-balance-sheet (OBS) or incognito leverage financing, seems to be straining the capacity of the historic cost framework to provide meaningful disclosure. Besides, it constitutes a severe problem for auditors in making their opinions on financial statements. Moreover, the introduction of new methods of valuation of assets, particularly "Fair Value" accounting has become highly controversial in both accounting literature and practice. Opposed to this, is the ancient historical cost accounting method, where assets are always carried and reported at a cost in the financial statements, irrespective of prevailing or current economic circumstances. [12] remarked that historical cost accounting methods have well-developed auditing techniques, but fair value accounting relies on crucial assumptions, modeling techniques, and judgment, which is prone to manipulations and misstatements. This was also the submissions of [53] and [4], whose opinion suggests that the world of accounting practice is implicated, especially in the area of financial reporting governing the valuation of assets. They argued that fair value accounting rules require companies to write-down financial assets to reflect plunging market values, and this according to them, poses some form of uncertainty, which creates a gap between theory and practice. The question is, at the time of acquisition of the asset, was the valuation not based on prevailing circumstance? If so, why the skepticism about adopting it now? Does the currency of the value undermine its relevance?

\subsubsection{The Cost and Management Accounting Domain}

Another concern in the accounting profession is the changing function of management accounting and the role of management accountants in commercial enterprises. [25] undertook a longitudinal research covering the period between 1995 and 1998, sponsored by professional bodies in the United Kingdom (Economic and Social Research Council) and United States (Chartered Institute of Management Accountants) points to evidence, that the role of management accounting is dynamically changing, from the traditional areas of costing and financial analysis to strategy and decision-making. A further study by the Institute of Management Accountant (IMA) in the United States revealed a rapid change in the role of management accountants between 1995 and 1999. [57, 18] observed a continuous increase in the rate in the future. The most common change factors, according to IMA, include globalization of markets, advances in information and production technologies, and increasing competition [9]. These, no doubt, affects the function and tasks of management accounting and accountants.

The globalization of markets and the increasing emphasis on improved customer relationships, products, services, and the enhancement of production technologies in contemporary times, have increased the level of competition between organisations [25]. There is a high competition on price, quality, speed of delivery, and customer service among firms.
Consequently, management accountants being the traditional information specialists of firms, need measures, and performance indicators on all these factors. Failure to do so, according to [14], may result in other information professionals bridging the gap, essentially rendering management accountants comparatively irrelevant. Consequently, professional bodies in a bid to measure up with the practical challenges mentioned above, have introduced some innovative costing and information frameworks such as; Activity Based Costing, Target Costing, Life Cycle Costing, Back Flush Accounting, Through Put Accounting, Balanced Scorecard, Key Performance Indicators, Economic Value Added, Benchmarking, Pareto Analysis, Customer Profitability Analysis, etc.

Although, the rise of new technologies considered as a challenge can relieve management accountants from 'beancounting' and 'number crunching' due to computerized accounting systems, thereby leaving them more time to analyze and interpret the information produced. How are practitioners fairing? How many practitioners are following this changing trend? [21].

\subsubsection{The Auditing and Forensic Accounting Domain}

The advancement of knowledge and technology in the business world has redefined the qualification(s) of an auditor, expressly or subtly. In the early days of auditing, the principal requirement for the position of an auditor was reputation [2]. An auditor was defined and known as a man known for his integrity and independence of mind. The matter of technical ability, as it is now emphasized, was entirely secondary. Thus, audit assignment and or function in those days was never confused with that of an accountant. However, like business transactions, governance and the accountancy profession progressively became more multifaceted and concerned with mechanics. Thus, auditors found themselves out of their depth and, in turn, became increasingly dependent upon the expertise provided by the accountants until, eventually, the audit function itself became dominated by the accountancy profession.

It is interesting to state that business transactions in the $21^{\text {st }}$ century are still unimaginably and uncontrollably becoming more complex. In the words of [12], our economy has moved from the "old economy" perspective of retail and manufacturing to a more service-based economy. She asserted that, as the world of commerce and business continues to change, the accounting profession and practitioners must respond to meet the challenges of auditing innovations.

There is an urgent need for all accountants to be ICT friendly and compliant. Else, with the emergence of accounting software and packages, the fear is that the accountant's job would soon be taken by ICT experts, who do not have the necessary and professional qualifications of accounting. However, the most significant concern is the ability of auditors to make a clean opinion on financial statements, whose figures and sources are highly computerized. There is, thus, an expansion of practice knowledge requirements in the accounting profession, which 
practitioners must acquire to remain relevant.

A more significant challenge in the auditing profession in contemporary times is the detection of financial crimes, fraud in an increasingly morally degraded society, and the controversial expectation of the society. Financial statements users and regulators expect external auditors to detect fraudulent financial reporting [5]. The social expectations are that auditors should play an active role in eliminating or reducing dysfunctional financial behaviour. The PCAOB Chairman categorically said that "detecting fraud is the responsibility of external auditors and that with few exceptions they should find it" (CFO.com 2004). Worse still, against the ancient saying that "auditors are not bloodhounds," current auditing standards are affirmatively imposing responsibility on auditors to obtain reasonable assurance, that the financial statements taken as a whole, are free from material misstatements due to fraud (PCAOB 2010; IAASB 2009, PCAOB 2002; AICPA 2002). [12, 3] observed that, in response to the discovery of accounting and auditing improprieties in the recent past, new rules, greater responsibility and increased scrutiny are being imposed on accountants and auditors alike, through the Sarbanes-Oxley Act.

Conversely, [47] observed that the rising spate of corruption (fraud), especially in the corporate world, poses a considerable challenge to auditors [32] in their duty of expressing a professional opinion on the state of financial statements. An environment that is riddled with corruption, poses a lot of problems to the auditing profession. Corruption according to [47] is a highly complex phenomenon, that inhibits the quality of audit service and weakens the institutions of good corporate governance. They opined that most directors of companies operating in corrupt environments, cook the books to hoodwink investors and amass a fortune to themselves, to the detriment of the resource owners.

The practical challenge faced by auditors in these times is that, while the profession of auditors expects them to concentrate on documentary or physical evidence, which can neither produce corrupt evidence, nor unveil organized and systematic (managerial) fraud, both the society and even some members of the profession believe that it is incumbent on auditors to discover and report fraud. This expectation gap constitutes a cross-road to auditors in their audit practice and or assignment today, and into the nearest future, until the accounting system comes up with a scientific way of transacting data capturing and gathering, that is not susceptible to fraudulent manipulation.

More interesting is that financial information is becoming more dynamic by the day. The dynamism of financial information is subtly redefining the scope and responsibilities of auditors, and practitioners are finding it difficult to cope, based on their ancient understanding. This is indicative that there is a knowledge or intellectual gap in the auditing profession. The electronic and complex nature of business activities, and the alarming rate of financial crimes, massive and very complex corporate fruads, corruption in modern times, unarguably call for new tools and more expertise on the part of auditors.

In the same vein, the perceived inadequacies of traditional audit knowledge, occasioned by the explosion of knowledge and information in this jet age, have prompted most Universities to introduce forensic accounting, to better equip the accouting profession against the monster of corruption and e-manipulations ravaging the financial world. In this regard, and particularly in Nigeria, it is worrisome to note that, due to the inherent inadequacies of conventional audit tools, the Federal Government now rely on anti-graft agencies namely, Economic and Financial Crimes Commission (EFCC) and Independent Corrupt Practices Commission (ICPC) headed by Police Officers and other personalities, with little or no financial training and experience, to investigate, detect, and prove fraud and corruption. It can, therefore, be argued that there is a great expansion of new knowledge requirements and methodologies in the accounting profession. Sadly, theoretical accounting knowledge seems to increase geometrically against practitioners' knowledge and experience, which appears to grow in an arithmetic order. This gap requires curtailing to retain the relevance of the profession and field in the coming age.

\subsubsection{The Public Sector Accounting Domain}

The expansion of knowledge in accounting is not limited to the private sector. The public sector has also been experiencing changes and advancements in know-how. Apart from different and numerous public sector reforms and policies introduced by governments of countries across the world, this branch of accounting has recorded a significant increase in accounting knowledge in the preparation of public financial statements and budget.

One of such expansion of knowledge in this area, is the emergence of International Public Sector Accounting Standards (IPSAS), introduced by the International Public Sector Accounting Standards Board (IPSASB), to regulate government accounting in response to calls for greater government financial accountability, transparency and value relevance. IPSAS is the center-piece of a global revolution in government accounting. The most important of this is the replacement of cash base accounting with accrual accounting, which is in line with IFRS (IFAC 2015).

Another notable advancement in knowledge in public sector accounting, is the introduction of the Medium-Term Expenditure Framework (MTEF) by the Western (European) world in collaboration with the World Bank to ensure fiscal planning, fiscal discipline, resource prioritization, transparency, etc. in government budgeting. Many countries, including Nigeria, have embraced and adopted both IPSAS and MTEF. However, most countries are still struggling with the implementation of these excellent standards and programmes. For instance, IPSAS is relatively new, especially in the Nigerian Public Sector. Hence practitioners (public sector accountants) are yet to recover from the agelong practice of cash accounting fully [50]. 


\section{Conclusion, Implications and Recommendations}

The focus of this treatise, was not to delve into the dialectics and epistemologies of the blame game in the theory-practice gap, that has held down, not just the development of new knowledge and methodologies in accounting, but even the deployment in practice, of the ones that have evolved despite, their vast presence in the literature of accounting and related fields. Instead, this study was approached from the future-reality paradigm, where techdriven developments in ICT and particularly AI, are fast eliminating traditional human career paths. The reality that applications software, will take over most of the practice domain of accounting is yet to be fully appreciated by professional accounting practitioners. This apparent lack of realisation is escalating the gap between accounting researchers and practitioners. From this diagnostic perspective, short of being a prophet of doom, this study is directed at tickling and provoking real future-survival reality thought, for accounting practice. The human accounting practice career domain might become the epicenter of disruption, on account of the Applications' invasion. While, massive career loss will bedevil the professional accounting practice enclave, in contrast, the academia will only experience a reduction in students' enrolment, leading to minor job losses, but find space and relevance in the emerging multi-disciplinary research paradigm.

Thus, gleaned from the preponderance of theoretical evidence, as reflected in the preceding academic literature expose', which underscores practitioners' continuing preference for normative, descriptive and immediate problemresolution research output, it is conclusive to aver that expanding the frontiers of accounting knowledge has been budged down by the limited scope of practice accommodation, given to new accounting methodologies, espoused via research outcomes. Thus, for as long as practitioners foreclose new knowledge deployment in practice, a consummate expansion of the accounting knowledge-base cannot be actualised. Accounting would continue to blaze the backward trail in new knowledge development, relative to other academic disciplines and professional practice.

The reality is that, while accounting practitioners want to hold on to their current state, the world that it serves, is moving forward. Great tech-driven changes are altering the status quo. With significant improvements in $\mathrm{AI}$, accounting practitioners may suddenly come to the reality where applications software would have taken over its routine function, thus decimating the human career path. Have accounting practitioners stopped to consider the fact that applications can efficiently be designed for a rule-based system, thus minimizing or possibly eliminating human intervention? In the light of the imminence of the "fourth industrial revolution," it is time for both sides of the divide to sheathe their swords and converge to chart a strategic alliance for the ultimate survival of the accounting human career path. We must emulate the theory-practice bond that has accentuated the ICT domain into its present overwhelming status, as both the positive and negative disruptive patterns cannot be foreclosed, given the speed of knowlegde expansion. The reality is that, only those who anticipate and undertake practical future-directed actions will remain relevant in the next industrial revolution. Furthermore, both practitioners and researchers must realise that while applied research is imperative for specific-problem resolution, basic research is the foundation for future knowledge growth. The nature of applied research is limiting in scope, as its definitive nature rests well within the framework of prescriptive domain. Future prospects for applied research is enabled only on the platform of a robust pure research base. Thus, the accounting epistemological domain must not discountenance current pure research as being irrevelant, because of its lack of specific and immediate problem resolution application. A critical mass of pure research outputs form the bedrock for future knowledge growth and applied research.

The accounting professional practice domain must move out of its comfort enclave and embrace new knowledge and methodologies, as exemplified in other fields of human academic and professional endeavour, where theory drives practice in some instances, and practice propels new theory development. A complete alignment in both, is the commonality that underscores fields where the front-ward knowledge trail is blazing. This mismatch in the accounting discipline and professional practice domain must be halted immediately, to avert the looming danger. The danger of continued crawling behind, is that with advances in artificial intelligence, accounting practitioners would soon find themselves in the burial ground of tech-disrupted and permanently quarantined careers, leaving the scene for only theoreticians to continue to extemporize new ideas. The entire accounting information chain as currently constituted, with developments in AI, is gravitating to the point where applications would do the whole of financial information gathering work, via the transaction chain, analyse same in various pre-formatted templates and scenarios, as well as making the information available to all users at the touch of a button. This era has already commenced in some areas. The scope is widening by the day, and it seems in the fourth industrial revolution, the current conservatism stand may become accounting's Hercules-heels, that would extinct the traditional human accounting career path. The urgency is fever pitch. The accounting human career chain is gradually ebbing away, like most of its allied traditional counterparts, that failed to innovate and paid direly.

Thus, accounting practitioners must be willing to accommodate knowledge expansion in light of society's continuous advancement, by a readiness to align with theory. While, at the same time researchers must indulge practitioners in a gradual shift, so as not to cause too much dislocation. Systematic gravitation would address this limbo and avert the imminent relevance loss threat. In addition, inspired by the success accounts of the deployment of diffusion theory in driving advances in theory and practice in 
most domains, all stake holders in the accounting theory and practice domain should adopt same, and thus espouse a combined effort to pragmatically undertake forward-looking measures, that can provide some form of hedging for the continued existence of the professional accounting career path and knowledge domain. Besides, practitioners for the sake of the fate of saving the accounting field, should be willing to fund futuristic research that would guarantee survival. Finally, accounting practitioners should be prepared to accommodate some degree of risk arising from new knowledge deployment. They must realise that many of the advances in various tech-driven fields, that shape our modern world and way of living, came at colossal human and material sacrifices. Repetitive efforts, after several failed attempts, is the common denominator that characterises all outstanding knowledge breakthroughs, that have informed the current human space. We should take a cue from this.

\section{References}

[1] Abdalla, Y. A., Siti-Nabiha, A. K. \& Shabidin, A. (2014). Social and environmental accounting research: the way forward. International Journal of Economics and Management, 8 (2), 365-388.

[2] Akpomi, M. E., \& Amesi, J. (2009). Behavioural constraints on practices of auditing in Nigeria. Educational Research and Review, 4 (10), 465-469.

[3] American Institute of Certified Public Accountants (2012). The Auditor's Responsibility to Detect and Report Errors and Irregularities, SAS 53. AICPA.

[4] Arnold, P. J. (2009). Global financial crisis: the challenge to accounting research. Accounting Organisations and Society, 34, 803-809.

[5] Asare, K. S., Wright, A. \& Zimbelman, F. M. (2015) Challenges facing auditors in detecting financial statement fraud: insights from fraud investigations. Journal of Forensic \& Investigative Accounting, 7 (2), 63-112.

[6] Baker, C. R. (2011). A genealogical history of positivity and critical accounting research. Accounting History, 16 (2), 207221.

[7] Baldvinsdottir, G; Mitchell, F \& Norreklit, H. (2010). Issues in the relationship between theory and practice in management accounting. Management Accounting research, 21, 79-82.

[8] Barbera, M. (1996a). Management accounting futures: Part 1. Charter, November 52-54.

[9] Barbera, M. (1996b). Management accounting futures. Charter, December 66-68.

[10] Baxter, W. T. (1988). Accounting research academic trends versus practical needs. The Institute of Chartered Accountants of Scotland.

[11] Belkaoui, A. (2004). Accounting Thoery. New York Cengage Publishing.

[12] Bies, S. S. (2004). Challenges Facing the Accounting Profession Today. Remarks by Member of the Board of Governors of the US Federal Reserve System, to the
Cincinnati Chapter of the Ohio Society of Certified Public Accountants.

[13] Billups, L. H. (1997). Reponse to bridging the research-topractice gap. Exceptional Children 63 (4): 525-527.

[14] Binnersley, M. (1997). Do You Measure Up? Charter, 3, $32-$ 35 .

[15] Bourdieu, P. (1975). The specificity of the scientific field and the social conditions of the progress of research. Social Science Information, 14, 19-47.

[16] Bricker, R. J. \&. Previts, G. J. (1990). The sociology of accountancy: a study of academic and practice community schisms. Accounting Horizons, 4 (1), 1-4.

[17] Brownson, R. M., Kreuter, B. B. \& Arrington, W. T. (2006). Translating scientific discoveries into public health action: how can schools of public health move us forward? Public Health Reports 121 (1), 97-103.

[18] Burns, J., Ezzamel, M. \& Scapens, R. (1999). Management accounting change in the UK. Management Accounting, 3, 2830 .

[19] Cohen, D. J. (2007). The very separate worlds of academic and practitioner publications in human resource management: reasons for the divide and concrete solutions for the bridging the gap. Academy of Management Journal, 505, 1013-1019.

[20] Dandago, K. I. (2015). What is the purpose of accounting research- to improve accounting practice or simply enrich literature. The Institute of Chartered Accountants of Nigeria.

[21] Dauda, I. A., Ombugadu, B. A. \& Aku, S. U. (2015) Threats and Challenges to Accounting Profession: A Draw Back to the Development of Accounting Practices in Nigeria. International Journal of Academic Research in Accounting, Finance, and Management Sciences, 5 (4), 96-104.

[22] Demski, J. S,(2001). Some thouhts on Accounting Scholarship. Presidential address on the forum of AAA.

[23] Donovan, C. (2005). The benefits of academic /practitioner collaboration, Accounting Education. An international journal, 14 (4), 445-452.

[24] Dyck, A., Morse, A. \& Zingales, L. (2010). Who blows the whistle on corporate fraud. Journal of Finance, 2213-2253.

[25] Forsaith, D., Tilt, C. \& Xydias-Lobo, M. (ND). The Future of Management Accounting: A South Australian Perspective, Flinders University School of Commerce Research Paper Series: 03-2.

[26] Gaffikin, M. (2009). Education for an accounting profession. Pacific Accounting Review, 2, 170-185.

[27] Ghosal, S. (2005). Bad management theories are destroying good management pratices. Academy of Mangement, Learning \& Education, 4, 75-91.

[28] Gopinath, C. \& Hoffman, R. C. (1995). The relevance of strategy research: Practitionerand academic viewpoints. Journal of Management Studies, 32 (5), 575-594.

[29] Gray, R., Collison, D. \& Bebbington, J. (1998). Environmental and Social Accounting and Reporting. The Centre for Social and Environmental Accounting Research, University of Dundee. 
[30] Green, L. W., Ottoson, J. M., Garcia, C. \& Hiatt, R. A. (2009). Diffusion Thoery and knowledge dissemination, utilization and intergration in Public Health. Annual Review of Publi Health, 30, 151-174.

[31] Gulati, R. (2007). Tent poles, tribalism, and boundary spanning: The rigor-relevance debatein management research. Academy of Management Journal 50 (4), 775-782.

[32] Hammersley, J. (2011). A review and model of auditor judgments in fraud-related planning tasks. Auditing Journal of Practice \& Theory, 30 (4), 101-128.

[33] Hodgkinson, G. P. \& Rousseau, D. M. (2009). Bridging the rigour-relevance gap in management research: it's already happening. Journal of Management Studies, 46, 534-546.

[34] IFAC (2015). International Public Sector Accounting Standards, Handbook of International Public Sector Accounting Pronouncements. New York.

[35] Inanga, E. L. \& Schneider W. B. (2005). The failure of accounting research to improve accounting practice: problem of theory and lack of communication. Critical Perspectives on Accounting, 16, 227-248.

[36] Ittner, C. D. \& Larker, D. F. (2002). Empirical managerial accounting research: Are we just describing management consulting practice? The European Accounting Review 11 (4), 787-794.

[37] Kaplan, R. S. (1986). The role for Empirical Research in management accounting. Accounting, Organizations and Society $11(4 / 5), 429-452$.

[38] Keefer, J. M. \& Stone, S. J. (2009). Practitioner perspectives on the gap between research and practice: what gap? Advances in developing human resources 11 (4), 454-471.

[39] Laughlin, R. C. (2011). Accounting Research, Policy and Practice: Worlds together or worlds Apart? In Evans, E: Buritt, R \& Guthrie, J. (Eds). Bridging thr gap between academic accounting research and professional practice. Sydney Centre for Accounting. Governance and Sustainability, University of South Australia and the Institute of Chartered Accountants of Australia.

[40] Lee, T. (1989). Education, practice and research in Accounting: gaps, closed loops, bridges and magic accounting. Accounting and Business Research. 19 (75), 237-253.

[41] Leisenring, J. J. \& Johnson, L. T. (1994). Accounting research: on the relevance of research to practice. Accounting Horizons, 8 (4), 74-79.

[42] Luft, J. \& Shields, M. D. C. (2002). Zimmerman's contentious conjectures: describing the present and prescribingthe future empirical management accounting research. European Accounting Review, 11 (4), 795-803.

[43] Malmi, T. \& Granlund, M. (2009). In search of management accounting theory. European Accounting Review. 18 (3), 597 620 .

[44] Merchant, K. A. \& Van der Stede, W. A. (2006). Field Based Researchin Accounting: Accomplishments and Prospects. Behavioural Research in Accounting 18, 117-134.

[45] Miller, B. W. (1977). What is accounting research research supposed to do? Management Accounting, 59 (6), 43-48.
[46] Mitchell, F. 2002. Research \& Practice in Management Accounting: Improving Intergratioon and communication. European Accounting Review. 11 (2): 277-289

[47] Modugu, P. K., Ohonba, N. \& Izedonmi, F. (2012). Challenges of auditors and audit reporting in a corrupt environment. Research Journal of Finance and Accounting, 3 (5), 77-82.

[48] Moehrle, S. R.: Anderson, K. L; Ayres, F. L; Bolt-Lett, C. E: Debreceny, R. S: Dugan, M. T; Hogan, C. E: Maher, M. W. \& Plummer, E. (2009). The impact of academic accounting research on professional practice: An analysis by the AAA Research Impact Task Force. Accounting Horizons, 23 (4), 411-456.

[49] Mohrman, S., Gibson, C. \& Mohrman, A. (2001). Doing research that is useful to practice: A model \& empirical exploration. Academy of Management Journal. 44 (2), 351375 .

[50] Odogu, T. K. Z. (2015). A comparative study of the adoption and implementation of MTEF by Ghana and Nigeria. MPhil. Thesis, University of Ghana, Legon.

[51] Parker, L. D., Guthrie, J. \& Linacre, S. (2011). The relationship between academic accounting research and professional practice. Accounting, Auditing and Accountability Journal, 24 (1), 5-14.

[52] Pfeffer, J. (2007). A modest proposal: How we might change the process and product of managerial research. Academy of Management Journal, 50, 1334-1345.

[53] Ryan, S. G. (2008). Accounting in and for the subprime crisis. The Accounting Review, 83 (6), 137-171.

[54] Rynes, S. L. (2007). Let's create a tipping point: What academics and practitioners can do alone and together. Academy of Management Journal, 50 (5), 1046-1054.

[55] Sandberg, J. \& Tsoukas, H. (2011). Grasping the logic of practice: theorizing through practical rationality. Academy of Management Review, 36, 338-360.

[56] Schipper, K. (994). Academic accounting research and the standard setting processs. Accounting Horizons, 8 (4), 61 73.

[57] Siegel, G. (1999). The pace of change in management accounting. Strategic Finance, 12, 71-72.

[58] Singleton-Green, B. (2010). The communication gap: Why doesn't accounting research make a greater contribution to debates on accounting policy?. Accounting in Europe, 7 (2), $129-145$.

[59] Splitter, V. \& Seidl, D. (2011). Does practice-based research on strategy lead to practically relevant knowledge? Implications of a Bourdieusian perspective. Journal of Applied Behavioural Sciences, 47, 98-120.

[60] Tucker, B. \& Lowe, A. (2011). Practitioners are from Mars; Academics are from Venus. Ann empirical investigation of the research-practice gap in management accounting", working paper presented at the AAA 2012. Management Accounting Section (MAS). 